\title{
ABSTRAK \\ BERTANYA, PEMICU KREATIVITAS DALAM \\ INTERAKSI BELAJAR
}

\section{Slamet Hariyadi, Dosen FKIP Universitas Jember, Jawa Timur, 085258822616, email: s.haryadi@gmail.com}

\begin{abstract}
Bertanya merupakan persoalan sederhana, walaupun tidak bisa digeneralisasi dalam perspektif pembelajaran bermakna. Bertanya bisa dipandang sebagai sikap perduli, responsif, dan interaktif terhadap materi pelajaran yang disampaikan. Kendala bertanya lebih banyak karena faktor diri siswa. Padahal bertanya dapat membangkitkan minat dan rasa ingin tahu. Jenis pertanyaan yang diajukan berbasis Taksonomi Bloom. Keterampilan bertanya mampu memicu kreativitias karena suatu pertanyaan muncul dari pertarungan kognitif antara konsep yang diterima dengan pengalaman yang pernah dialami, ditambah pengetahuan lama yang dipunyai dan keyakinan personal terhadap konsep tersebut.
\end{abstract}

\section{Kata kunci: bertanya, keterampilan}

\begin{abstract}
The question is a simple issue, although can not be generalized in meaningful learning perspective. A question could be viewed as an care attitude, responsive, and interactive with the subject matter presented. Some constraints to ask caused of the student's factor, meanwhile it's can generate interest and curiosity. The type of questions based on Bloom's Taxonomy. The questioning skill triggering creativity, where a question arise from combining by cognitive accepted concept with the experience he had ever experienced, and the knowledge that belongs to a long and beliefs of the concept.
\end{abstract}

Keywords: Asking, triggers creativity

Bertanya merupakan metode untuk menjadi pendorong atau perangsang mengungkapkan rasa ingin tahu yang efektif untuk belajar dan mencari terhadap jawaban yang tidak atau jawaban (Suhito, 1987; dalam Ribowo, belum diketahui. Rasa ingin tahu inilah 2006). Namun disayangkan fakta 
dilapangan masih banyak dari siswa yang justru tidak respon saat guru bertanya atau memberikan kesempatan untuk bertanya di kelas. Fakta menarik dari pengamatan dalam proses pembelajaran IPS di SMP $\begin{array}{lll}\text { Muhammadiyah } & 2 & \text { Surakarta }\end{array}$ didapatkan data tentang kesiapan untuk mengajukan pertanyaan hanya $2,7 \%$. Angka ini jauh di bawah hasil data yang lain diantaranya kesiapan menerima pelajaran $(43,24 \%)$, memperhatikan penjelasan guru $(35,13 \%)$, konsentrasi penuh $(35,13 \%)$, mencatat hasil pembahasan $(32,43 \%)$ (Soufia, dalam Winasih, 2009). Secara logika, bila seseorang sudah menerima pelajaran dengan memperhatikan guru saat pembelajaran, berkonsentrasi dan mencatat hasil dari proses pembelajaran, maka siap untuk memberikan respon melalui pertanyaan. Kenyataannya jauh antara data tersebut dengan kesiapan untuk mengajukan pertanyaan.

Hal ini bisa mengindikasikan bahwa siswa masih belum banyak paham tentang kaidah unsur bertanya atau kurang responsif terhadap proses belajar itu sendiri. Winasih juga mengemukakan bahwasiswa takut atau jarang bertanya karena adanya tekanan pribadi, atau faktor guru yang jarang memberikan kesempatan pada siswa untuk bertanya atau siswa lebih suka bertanya pada teman. Perasaan malu atau takut untuk bertanya yang terjadi saat siswa masih duduk di bangku sekolah berpeluang akan berlanjut sampai dewasa. Kebiasaan yang ditanam sejak masih kecil, akan membentuk pola pikir yang sama saat ia telah besar nanti. Hal ini sejalan dengan teori operant conditioning dari Skinner yang menyatakan bahwa pemberian reinforcement (baik positif atau negatif) dapat mengakibatkan terbentuknya perilaku berikutnya (baik yang diharapkan atau yang tidak diharapkan) yang dapat berlangsung lama (Santrock, 2008). Hal ini menyedihkan bila pola pikir yang terbentuk adalah pola pikir malu, enggan atau takut bertanya karena pemberian reinforcement yang negatif tadi. Bagaimanapun juga kegiatan bertanya adalah suatu hal yang penting untuk membuka wawasan dan mencari informasi yang ingin diketahui. 


\section{PEMBAHASAN}

Isadore Rabi, pemenang hadiah

Nobel Fisika mengaku bahwa ibunya selalu bertanya setiap ia pulang sekolah. Pertanyaannya bukan Apa yang kamu pelajari hari ini?, melainkan bertanya, Apa pertanyaan bagus yang kamu tanyakan hari ini?. Ibunya tahu akan kekuatan bertanya dan tahu akan pentingnya menghubungkan konsep dengan bahan yang cukup untuk dapat merumuskan pertanyaan dalam rangka mempelajari materi lebih lanjut (Walsh, 2011). Ternyata dari induksi ibunya yang terus mendorong anaknya memberikan pertanyaan terbaiknya, membangun karakter Rabi untuk memperluas wawasan dari konsep yang dipelajari dan membuka ujung misteri pengetahuan dengan mencetuskan pertanyaan terlebih dahulu. Bukankah Isaac Newton memulai penjelajahan ilmu pengetahuannnya dengan mempertanyakan apa yang di lihatnya: Mengapa buah apel selalu jatuh ke tanah?, Mengapa planet bergerak mengitari matahari?, Mengapa satelit tidak jatuh ke permukaan bumi? Partikel-partikel apakah yang membentuk cahaya?. Penjelajahan ilmu pengetahuannya di dahului dengan bertanya tentang asal muasal dari segala yang dilihatnya. Filosof-filosof lain juga memulai debutnya dengan bertanya sebagai starting point. Awal dari filsafat adalah bertanya, bertanya dan bertanya tentang apa saja, tentang kehidupan, realitas sehari-hari atau makna dari suatu peristiwa. Para penemu juga memulai dari pertanyaan setelah terjadi pertentangan antara harapan dan kenyataan yang dialaminya.

\section{Kendala dalam Mengajukan Pertanyaan}

Perlu ditelusur penyebab siswa malas mengajukan pertanyaan, karena dengan mengungkap akar masalah ini akan dapat dicarikan solusi yang baik guna meningkatkan peran siswa dalam proses belajar mengajar. Terdapat banyak alasan mengapa siswa malas atau takut bertanya, diantaranya takut dianggap bodoh, buang-buang energi, khawatir tersinggung, berpikir yang ditanya tidak paham jawaban, sulit menemukan kata yang cocok dalam kalimat tanya, tidak diberi kesempatan bertanya, tidak berpengaruh pada 
apapun, menunggu kesempatan yang pas, takut menimbulkan konflik, khawatir memicu pertengkaran, tidak ada ide, semua materi sudah dianggap mengerti dengan baik, ada yang lebih penting daripada bertanya, takut disangka iseng, dan sebagainya.

Menurut Walsh (2011) faktorfaktor penyebab siswa tidak mau bertanya antara lain karena siswa tidak perduli dengan materi, menganggap materi tidak mutakhir, takut dianggap bodoh, gurunya tidak suka bertanya, dan anggapan bahwa pembelajaran itu tugasnya guru, bukan tugasnya siswa sehingga berpikir siswa tidak perlu capek-capek menyusun pertanyaan dalam pembelajaran. Padahal kemampuan untuk mengajukan pertanyaan yang baik telah menjadi sangat penting dalam beberapa tahun terakhir karena ledakan informasi dan kebutuhan bagi individu untuk secara efektif mengelola interaksi mereka dengan suatu informasi, baik secara pribadi maupun profesional.Orangorang di semua profesi harus memperbarui pengetahuan dan keterampilan mereka terus-menerus melalui mengajukan pertanyaan dan mencari jawaban.

Urip (2012) mengemukakan ada delapan alasan mengapa siswa enggan bertanya. 1). siswa tidak paham sedikitpun tentang yang ia pelajari sehingga tidak tahu apa yang ditanyakan; 2). siswa tidak memahami apa yang menjadi kesulitan dirinya selama belajar atau selama mengikuti pelajaran di kelas; 3). siswa menerima apa adanya tentang semua yang ia dengar dari guru sehingga tidak terbiasa berpikir kritis; 4). siswa tidak pernah belajar di rumah, sehingga tak pernah menemukan masalah dari keterangan yang disampaikan guru; 5). siswa sudah mengerti tentang apa yang dijelaskan guru, sehingga tidak perlu bertanya; 6). siswa takut pertanyaan yang akan diajukan malah akan membuatnya malu, karena dianggap bodoh; 7). faktor guru yang menyebabkan siswa enggan bertanya, karena ada beberapa guru yang sering mengkritik pertanyaan siswa dan tidak membantu memperbaiki pertanyaan siswa; 8). kadang dalam suatu kelas ada saja siswa yang dominan dibanding yang lain, akhirnya siswa lainnya 
menjadi minder untuk mengajukan pertanyaan.

Lain halnya dengan Matra Pendidikan (2014) yang mengungkap ada 3 penyebab utama siswa enggan bertanya di kelas: 1). cara guru bertanya.Tidak jarang guru bertanya sekenanya ketika sedang mengajar, mengakibatkan siswa bingung mau menjawab apa. Pertanyaan guru datangnya tiba-tiba, membuat siswa terkejut sejenak dan bingung tak tentu arah.Seringkali kalimat yang digunakan guru tidak dapat dimengerti oleh siswa.Suara dan intonasi guru tidak tepat ketika mengajukan pertanyaan.Tatapan mata guru tidak fokus pada siswa; 2). sikap guru saat mengajar.Sikap guru yang kaku dan otoriter dalam mengajar sering berdampak secara psikologis terhadap siswa.Siswa akhirnya berpikir lebih baik baik diam daripada cari perkara.Mereka jadi takut salah menjawab pertanyaan guru; dan 3 . budaya mengejek di kelas.Ini adalah budaya jelek siswa yang harus dikikis habis.Jika ada salah seorang siswa bertanya maka teman lainya sering mentertawakan atau mengejek. Jika ada siswa yang menjawab pertanyaan guru dan kebetulan salah jawabannya dicemooh oleh teman lain.

Sukasains (2011) memberikan pandangan yang hampir sama. Menurutnya terdapat enam alasan yang membuat siswa enggan atau tidak berani bertanya, diantaranya adalah takut dianggap bodoh atau ditertawakan teman lain, takut malah disuruh maju menyelesaikan soal yang ditanyakan ke depan kelas oleh guru, takut jika diminta menjelaskan ulang materi yang baru saja disampaikan oleh guru, takut di dakwa tidak membaca materi pelajaran atau kurang memperhatikan guru saat pelajaran berlangsung sehingga sama sekali tidak paham materi, bingung cara menyampaikannya (tidak dapat menyusun kalimat dengan baik), dan kadang ada guru yang justru marah saat siswa bertanya sesuatu di kelas. Hal ini diperkuat juga oleh Tamasandi (2014) yang mengungkapkan ada lima hal yang menyebabkan siswa tidak suka bertanya: 1). merasa sudah mengerti tentang pelajaran yang baru diberikan.Hal ini sangat sering terjadi pada semua siswa, baik siswa yang 
pandai sampai yang malas. Siswa yang sering melakukan hal ini biasanya mudah lupa materi saat ujian, dan hanya paham pada saat diajarkan saja.;

2). malas bertanya atau dapat dikatakan tidak jujur, karena ketika mereka sebenarnya tidak bisa namun mereka mengatakan tahu; 3) takut terhadap guru karena mudah marah menyebabkan murid takut untuk menanyakan sesuatu yang ingin ditanyakan; 4). bingung terhadap apa yang ingin ditanyakan. Siswa yang seperti ini lebih baik dari pada alasan di atas, karena siswa yang seperti ini masih merasa dirinya belum bisa dan masih membutuhkan penjelasan gurunya namun ia bingung apa yang ingin ditanyakan; dan 5) malu karena kurang akrab atau familiar dengan guru.

Pendapat-pendapat di atas dapat ditarik benang merah bahwa kendala siswa untuk bertanya lebih disebabkan oleh faktor internal (dirinya sendiri) dan faktor eksternal (faktor guru). Ada tiga opsi terbanyak yang ditemukan dari diagnosa keengganan siswa bertanya, yakni tidak ada ide bertanya karena tidak paham materi yang dijelaskan, takut dianggap bodoh atau tidak perduli dengan materi yang sedang dijelaskan. Opsi pertama menyangkut diri siswa, yakni ketidaksiapan dalam belajar atau ketidakmampuan mencerna materi mengakibatkan siswa tidak mampu mencetuskan pertanyaan dan tidak paham mau bertanya apa. Seseorang yang tidak memahami alur cerita, tidak mengerti pemetaan konsep yang dijelaskan, tidak terang dengan gambaran materi maka tidak mungkin mempertanyakan materi tersebut. Mereka seolah berjalan di kegelapan jalan dan sulit mendeteksi apa yang diinjaknya. Opsi kedua yakni takut dianggap bodoh.Mindset ini muncul karena anggapan bahwa bertanya itu hanya menanyakan materi yang telah jelas diungkap, tetapi tidak pernah berpikir bahwa bertanya itu banyak tingkatannya, banyak tipenya dan banyak hal yang bisa ditanyakan, yang daripada belum tentu sesederhana yang diduga kebanyakan orang. Kualitas pertanyaan yang baik tidak mengulang apa yang telah dijelaskan, tetapi mampu memberikan perspektif lain dari hal yang ditanyakan dan justru 
menambah informasi baru dari rentang masalah yang telah disajikan.

Opsi ketiga tidak perduli terhadap materi yang dijelaskan.Sikap acuh yang ditunjukkan siswa bisa disebabkan oleh banyak faktor, diantaranya kemampuan berpikir siswa yang kurang intens, kurang luasnya pengetahuan awal siswa yang dipunyai, kurang dalamnya pengalaman siswa yang pernah dialami, atau mood belajar yang terjadi saat pembelajaran yang kurang optimal. Dari sisi guru bisa jadi ketidakperdulian siswa disebabkan guru yang tidak memberikan kondisi baik untuk siswa mengajukan pertanyaan, guru yang tidak suka berargumentasi karena sempitnya pengetahuan yang dimiliki, atau guru yang merasa diuji bila ada pertanyaan dari siswa, sehingga suasana pembelajaran bersifat one way traffic communication. Kendala-kendala ini perlu menjadi perhatian bersama dan dapatnya menjadi kesadaran guru dan siswa supaya dapat segera mendapatkan solusinya.

\section{Pentingnya} Pertanyaan

Bertanya dapat membangkitkan minat dan rasa ingin tahu siswa terhadap suatu pokok bahasan, mendiagnosis kesulitan-kesulitan khusus yang menghambat siswa belajar, memberikan kesempatan kepada siswa untuk mengkritisi suatu informasi yang ia dapatkan, mendorong siswa mengemukakan pendapatnya dalam diskusi, dan menguji dan mengukur hasil belajar siswa (Ribowo, 2006). Hal ini diperkuat oleh Morgan \& Saxton (2006) yang menyatakan bahwa mengajukan pertanyaan berkualitas dapat mengeksplorasi peran penting dari suatu pertanyaan dalam menciptakan lingkungan belajar yang baik. Hasil riset menyatakan bahwa orang yang mengajukan pertanyaan adalah pembelajar aktif, walaupun masih banyak ruang-ruang kelas yang berkutat pada pertanyaan guru.Diakui oleh guru-guru senior bahwa dibutuhkan waktu dan ketekunan untuk menjadi penanya yang efektif.

Sehubungan dengan itu perlu sekali membantu guru untuk memahami mengapa bertanya itu 
sangat penting dalam belajar mengajar; menunjukkan cara yang tidak rumit untuk mengklasifikasikan pertanyaan guru yang dibutuhkan dalam rangka memperoleh informasi, membangun pemahaman, dan menghasilkan refleksi. Ketiga bagian klasifikasi dari pertanyaan-pertanyaan ini akan membangun konteks untuk pemahaman bersama dan ini menantang siswa untuk berpikir kritis dan kreatif, menawarkan model, teknik, kegiatan, dan contoh-contoh yang mempromosikan pertanyaan yang lebih baik oleh guru dan siswa, memungkinkan untuk berbagai entry point berdasarkan kepentingan dan kebutuhan guru kelas. Pikiran dan perasaan adalah komponen penting dari kelas yang dapat mendorong keinginan bertanya. Dengan demikian penting guru mengajukan pertanyaan yang tepat pada saat yang tepat, menyediakan berbagai sikap mengajar, peran, dan situasi yang akan meningkatkan kemampuan mengemas bahasa dan mendorong berpikir luas. Lain halnya dengan McTighe (2013) menyatakan bahwa bertanya itu penting, dan perlunya menyusun pertanyaan berbeda dari pertanyaan lain. Maka itu pertanyaan itu perlu dirancang dan digunakan saat di kelas.Pertanyaan penting (Essential Questions) membantu guru mencapai sasaran standar seperti yang diamanatkan dalam konten kurikulum, menjadi unit-unit yang koheren yang menghasilkan pembelajaran terfokus dan bijaksana.

Umumnya bertanya merupakan cara seseorang untuk menelusuri bagian yang belum dipahami. Wilayah mana yang akan menjadi pertanyaan tergantung pada keluasan seseorang untuk memetakan materi yang baru dialami. Semakin luas materi yang dapat dihubungkannya dengan pengetahuan, pengalaman dan keyakinannya, semakin jauh pertanyaan yang akan diajukan; dan sebaliknya semakin sempit menghubungkannya dengan apa yang dimiliki, semakin dekat pertanyaan di seputar materi yang dijelaskan. Pertanyaan bisa juga diajukan untuk meyakinkan konsep yang diterima. Saat seseorang menyerap informasi baru, akan diolah secara cepat melalui pikiran dan perasaan, kemudian dari 
interpretasi hasil olahan bisa jadi ada bagian grey area. Hal seperti inilah yang membutuhkan statement narasumber atau guru yang meyakinkan keraguannya.

Unsur bertanya juga dapat mencari bagian tertentu untuk dihubungkan dengan pengalamannya. Ada bagian lain yang tidak langsung berhubungan dengan materi dan dicoba untuk dihubung-hubungkan melalui pertanyaan-pertanyaan yang diajukan. Namun yang terpenting dari sebuah pertanyaan menurut pendapat Pythagoras (dalam Sentanu, 2007) bahwa kualitas hidup seseorang ditentukan oleh kualitas pertanyaannya, dimana semakin progresif sebuah pertanyaan, semakin sukses orang tersebut dalam menjalani kehidupannya.

\section{Jenis-jenis Pertanyaan}

Sebenarnya bertanya tidak sekedar mengajukan kalimat yang meminta jawaban, karena bertanya mempunyai tipe dan tingkatan. Morgan (2006) megemukakan tentang jenisjenis pertanyaan berdasarkan tahapantahapan Taksonomi Bloom. Pertanyaan pengetahuan menggunakan kata apa, siapa, mengapa, kapan, dimana, dan bagaimana. Pertanyaan pemahaman lebih kepada pengertian, maksud dan tujuan, kegunaan, dan lain-lain.Untuk pertanyaan penerapan berorientasi pada pendapat atau opini. Pertanyaan analisis dikemas melalui cara langkahlangkah, contoh, akibat, dan lain-lain. Pertanyaan sintesis diajukan melalui cara menghubungkan suatu informasi dengan pengetahuan yang sudah ada. Pertanyaan evaluasi mengandung kritikan, dorongan, kesimpulan, opini, dan lain-lain (Morgan \& Saxton, 2006).

Walsh (2011) berpendapat beda, menurutnya ada 10 jenis-jenis pertanyaan yang selama ini diobservasi, diantaranya pertanyaan penting, pertanyaan terkait, pertanyaan diagnostik, pertanyaan periksa, pertanyaan menyelidik, pertanyaan inferensi, pertanyaan interpretasi, pertanyaan transfer, pertanyaan prediksi, dan pertanyaan refleksi. Pertanyaan Penting, mempunyai tipe terbuka/tertutup dan berbasis konseptual, serta mengintegrasikan fakta-fakta di seputar gagasan atau konsep utama; Pertanyaan Terkait, ini sengaja dirancang untuk memicu rasa 
ingin tahu dan keinginan siswa, tidak memiliki satu jawaban saja, terletak di inti pelajaran atau unit, dinyatakan dalam bahasa yang jelas yang dapat dipahami oleh siswa; Pertanyaan Diagnostik, tujuannya mengkritik komponen desain dari pelajaran atau unit, sering di buat oleh guru menggambarkan pengalaman mereka dalam mengajar konsep pada kelompok siswa sebelumnya membentuk pertanyaan seputar konsep dan atau keterampilan dengan kelas yang sebelumnya mengalami kesulitan, paling sering diajukan serta dijawab secara tertulis atau dicantumkan dalam grafik KWL (Know, Want to know, Learned); Pertanyaan Periksa, pertanyaan yang digunakan untuk mengecek pemahaman siswa, dapat direncanakan sebelum pelajaran atau bertanya secara spontan.

Guru dapat merancang penilaian formatif untuk menghasilkan informasi yang dapat mereka gunakan untuk menginformasikan langkah pembelajaran berikutnya dan siswa dapat menggunakannya untuk memodifikasi strategi baru terhubung ke situasi kehidupan pembelajarannya. Jika spontan, nyata yang siswa dapat hubungkan; pertanyaan tersebut dapat ditanyakan ketika guru merasa bahwa siswa tidak mengikuti logika belajar dan memutuskan untuk memverifikasi dugaan ini; Pertanyaan Menyelidik, biasanya muncul selama interaksi siswa ke guru atau siswa ke siswa siswa yang tidak benar, tidak lengkap, atau tidak jelas; Pertanyaan Inferensi, menuntut siswa untuk menggunakan bukti guna menarik kesimpulan sementara, fokus pada pemikiran siswa dan direncanakan sebagai bagian dari desain pelajaran, meminta siswa untuk mensintesis informasi \& menyarankan hasil yang memungkinkan; Pertanyaan Interpretasi $i_{s}$ meminta siswa untuk membuat makna sendiri dan atau secara pribadi mengevaluasi isi konsep, membutuhkan penetapan kriteria atau standar berdasarkan penilaian atau penafsiran, mungkin lebih tepat untuk menulis tanggapan; Pertanyan Transfer, membutuhkan siswa untuk menerapkan informasi dalam pengaturan baru, dan meningkatkan relevansi pembelajaran jika setting nyata yang siswa dapat hubungkan; PAGE 152 lainya, fokus pada sebagian respon

(PAt 152 
Pertanyaan Prediktif, melibatkan siswa dalam pola berpikir "jika-maka" dan memberi peluang untuk pola pikir terbuka, karena tidak ada jawaban yang mutlak benar; Pertanyaan Reflektif, meminta siswa untuk menilai hubungan pribadi mereka dengan isi konsep yang mereka pelajari dan harus direncanakan terjadinya titik-titik strategis dalam pelajaran untuk mendorong rasa kepemilikan siswa dalam belajar.

\section{Memicu Kreativitias melalui Bertanya}

Menurut Kamus Besar Bahasa Indonesia (kkbi.com) arti kreatif adalah mempunyai daya cipta atau mempunyai kemampuan menciptakan. Dalam pengertian luas, kreatif merupakan aktivitas kreasi dari seseorang untuk memunculkan hal baru dari situasi umum, yang memberikan nuansa berbeda dari yang pernah diketahui.Sementara Munandar (2002) mendefinisikan kreativitas sebagai kemampuan yang mencerminkan kelancaran, keluwesan, dan orisinilitas dalam berpikir serta mampu untuk mengelaborasi suatu gagasan. Ciri-ciri orang yang memiliki kemampuan berpikir kreatif yang tinggi yaitu memiliki dorongan rasa ingin tahu yang besar, sering banyak gagasan dan usul terhadap suatu masalah, bebas dalam menyatakan pendapat, menonjol dalam salah satu bidang seni, memiliki pendapat sendiri dan mampu mengutarakannya, tidak mudah terpengaruh orang lain, daya imajinasi kuat, memiliki tingkat orisionalitas yang tinggi, dapat bekerja sendiri, senang mencoba hal-hal yang baru, dan sering mengajukan pertanyaan yang baik.

Pendapat ini didukung oleh Rahmawati (2012), yang menyatakan bahwa untuk mendukung kreativitas anak, perlu diciptakan suasana yang menjamin terpeliharanya kebebasan psikologis, dimana untuk anak usia prasekolah akan memiliki kreativitas alamiah bila tampak dari perilaku mereka yang sering bertanya. Kreativitas bisa berarti kemampuan berpikir beragam yang ditandai dengan ide-ide yang mengalir lancar (Fluency), memikirkan berbagai macam pemecahan masalah (Flexible), mencari hal baru yang belum pernah ada (Originalitas), melakukan tuntas, 
detil dari berbagai sudut pandang (Elaborasi). Ciri-ciri anak kreatif selalu ingin tahu, tidak puas dengan satu jawaban, eksploratif dan suka mencoba hal-hal yang tidak biasa.Bila anak terus bertanya dan dirasakan cukup mengganggu maka orangtua dapat menyiasatinya dengan memberikan satu buku tulis yang diberi judul "Buku Rasa Ingin Tahuku", sehingga anak bisa menuliskan pertanyaanpertanyaannya di buku tersebut.Saat orangtua sedang tidak sibuk, dapat mencari jawaban pertanyaan tersebut bersama-sama si anak melalui buku atau browsing internet.

Dalam hal bertanya, unsur yang dimunculkan berasal dari pertarungan kognitif antara konsep yang diterima dengan pengalaman yang pernah dialami, ditambah pengetahuan lama yang dipunyai dan keyakinan personal terhadap konsep tersebut. Selanjutnya selama proses penyerapan itu berlangsung, sepanjang itu pula interaksi antara keempat komponen di atas juga berlangsung. Bila terjadi sinergitas yang baik, maka siswa mengalami proses pemahaman yang baik pula, sebaliknya bila ada polarisasi kognitif yang terjadi, siswa mengalami divergensi konsep yang berujung pada letupan permasalahan. Hal inilah yang menjadi bahan untuk bertanya. Tahap berikutnya adalah masalah keberanian hati untuk mengangkat tangan atau kemampuan memilih kata yang tepat dan mengemasnya dalam bentuk kalimat yang akademis, atau bahkan memilih timing yang tepat. Keberanian mengangkat tangan kadang menantang adrenalin untuk berani menjadi fokus perhatian diantara siswa yang lain dan tidak takut dicemooh. Tidak semua orang yang punya keberanian menjadi pusat perhatian karena dibutuhkan motivasi yang tinggi dan semangat belajar yang berkobar. Bahkan ada relevansi yang signifikan antara orang yang percaya diri dan orang yang berani bertanya.Untuk itu dalam Quantum Learning (De Porter, 1999) sangat melarang guru memasung siswa yang berani bertanya dengan menyalahkan atau mengejek, tetapi harus tetap dihargai dan diapresiasi.

Russanti (2012) memberikan metode untuk memicu kebiasaan bertanya pada siswa, yang bisa 
dilakukan di awal semester. Pertama dengan meletakkan sebuah benda di dalam kotak, seperti buku, ballpoint, penggaris, dan sebagainya. Guru kemudian memberikan kata kunci untuk menebak benda yang ada di dalam kotak, semisal bentuknya persegi. Dengan kata kunci ini pasti sangat umum sekali, sehingga memicu siswa untuk mengembangkan pertanyaan, apakah persegi empat atau persegi panjang. Guru hanya menuntun jawaban dengan menyebutkan ya atau tidak. Walaupun pertanyaan yang disusun siswa sederhana dan persoalan yang ditawarkan juga sederhana, tetapi interaksi ini melatih siswa untuk tidak berdiam diri dengan ketidaktahuan atau ketidakpahaman terhadap sesuatu. Siswa dilatih untuk menghubungkan pengetahuannya, pengalamannya dan keyakinannya dengan fakta yang diungkapkan oleh gurunya.Persepsi ini yang digunakan untuk menyusun pertanyaan demi pertanyaan, sampai siswa dapat menebak isi kotak dengan tepat. Selanjutnya siswa yang mampu menebak dengan benar tersebut akan diberitahukan isi kotak berikutnya dan diminta untuk memandu siswa-siswa lain dengan memberikan kata kunci dan menjawab ya atau tidak dari pertanyaan demi pertanyaan yang dilontarkan teman-temannya.

Kegiatan ini mampu melatih keterampilan pendengaran secara produktif, pengetahuan secara kreatif dan terbiasa menghubung-hubungkan pengetahuan yang dimiliki dengan kata kunci yang diberikan. Kegiatan kedua yang bisa memicu keterampilan bertanya adalah dengan permainan tebak menebak mirip cara pertama. Metodenya dengan meminta salah seorang siswa maju kedepan, berdiri membelakangi papan tulis lalu guru menuliskan sesuatu di papan tulis dengan huruf yang besar dan bisa dibaca dengan baik oleh siswa yang duduk di bangku. Langkah berikutnya guru memberikan kata kunci, lalu siswa yang menjadi obyek mulai melontarkan pertanyaan demi pertanyaan pada semua siswa yang duduk. Seperti pada pola kegiatan pertama, mereka hanya boleh menjawab ya atau tidak. Cara ini bisa juga dimodifikasi seperti kuis yang ada di televisi, yaitu mencantumkan kata di helm seorang siswa, lalu siswa yang 
memakai helm tersebut menanyakan kata yang dimaksud pada teman lain. Kegiatan ini akan merangsang siswa untuk mengekplorasi pengetahuannya, menelusuri ketidaktahuan terhadap sesuatu, sehingga tergugah untuk menyusun pertanyaan guna mengungkap ketidaktahuannya.

Metode ketiga yakni dengan membawakan suatu benda yang dianggap asing oleh siswa. Benda tersebut diletakkan di meja depan kelas. Selanjutnya siswa diminta untuk menyampaikan hal apa yang ingin diketahui dari benda tersebut. Guru menuliskan semua hal yang diusulkan oleh siswa di papan tulis. Selanjutnya dibuat suatu peta konsep dari semua yang tertulis untuk dibahas satu per satu.Pembahasan tidak dilakukan secara deskriptif, tetapi guru harus memancing dengan pertanyaanpertanyaan yang mengarahkan kepada jawaban. Jika telah terjawab satu poin, guru bisa melanjutkan pembahasan melalui pertanyaan ke poin lain yang berhubungan sesuai peta konsep yang telah dibuat di awal. Setiap fakta baru yang telah ditemukan melalui jawaban, guru menuliskannya di papan.Dengan demikian bila semua fakta telah terungkap, siswa dapat mengetahui secara komprehensif misteri dari benda asing yang dihadirkan di kelas. Mengingat siswa tidak dibatasi konten pertanyaannya, bisa meluas dan mendalam, maka bila ada suatu fakta yang tidak bisa terungkap akibat terbatasnya pengetahuan guru, maka bisa diskip ke fakta berikutnya, mengingat kegiatan ini titik tekannya bukan pada pengetahuannya semata, tetapi melatih siswa untuk mampu melacak area ketidaktahuan, merespon rasa keingintahuan, melihat sesuatu dari sudut pandang lain, kemudian mengemasnya menjadi sebuah pertanyaan dan berani mengungkapkan di depan kelas. Bila metode ini berhasil, siswa akan terlatih untuk mengajukan pertanyaan yang berkualitas. Di abad 21 yang serba digital siswa tidak cukup hanya duduk diam menunggu guru bertanya.Mereka harus tanggap dan merespon peristiwa dengan berpikir kritis, yaitu dengan bertanya yang berkualitas. Dengan kata lain mereka harus mampu menyusun pertanyaan yang jawabannya lebih dari satu kata dan membutuhkan penjelasan. 


\section{KESIMPULAN}

Dari uraian di atas disimpulkan bahwa keterampilan bertanya sangat penting dalam interaksi belajar mengajar yang dapat meningkatkan kreativitas siswa. Disarankan bagi guru untuk memberikan peluang yang memadahi bagi suasana belajar yang interaktif guna menggugah inisiatif siswa untuk berani dan mengajukan pertanyaan

\section{DAFTAR RUJUKAN}

Aji, P. 2008. Usaha Meningkatkan Keberanian Siswa Mengerjakan Soal-Soal Latihan di Depan Kelas Melalui Pendekatan Kooperatif Tipe STAD (Student Team Achievement Division). Skripsi. Universitas Muhammadiyah Surakarta. Surakarta:

Departeman Pendidikan Nasional Republik Indonesia 2008. Kamus Besar Bahasa. Jakarta: Departeman Pendidikan Nasional Republik Indonesia http://pusatbahasa.diknas.go.id/k bbi/index.php 05.07.2010_12.10

De Porter, B. 2000. Quantum Teaching. (Terjemahan Ary Nilandari). Mizan Pustaka. Jakarta

Greenstein, L. 2012. Assessing $21^{\text {st }}$ Century Skills: A Guide to Evaluating Mastery and Authentic Learning. SAGE Publication Ltd. London:
Hotimah, N.H. 2009. Optimalisasi Kemampuan Koneksi dan Keaktifan Siswa Melalui Pendekatan Improving Learning dalam Pembelajaran Matematika. Skripsi. Universitas Muhammadiyah Surakarta. Surakarta

Johnson, E. B. 2002. Contextual Teaching \& Learning: Menjadikan Kegiatan BelajarMengajar Mengasyikkan dan Bermakna. Mizan Learning Center (MLC). California

Matra Pendidikan. 2014. Mengapa Siswa Enggan Bertanya. http://www.matrapendidikan.com /2014/02/mengapa-siswa-engganbertanya.html\#ixzz32msTHlce [27 Mei 2014]

McTighe, J \& Wiggins, G . 2013. Essential Questions: Opening Doors to Student Understanding. Association for Supervision \& Curriculum Development Pub. United Kingdom

Morgan, N \& Saxton, J. 2006. Asking Better Question. $2^{\text {nd }} E d$. Pembroke Publishers. Canada

Munandar, $\quad$ S.C.U. 2002. Pengembangan Kreativitas Anak Berbakat. Rineka Cipta. Jakarta

Rahmawati, S. 2002. Mencetak Anak Cerdas dan Kreatif. Penerbit Buku Kompas. Jakarta

Ribowo, B. 2006. Upaya Meningkatakan Hasil Belajar Siswa Kelas IIA SMP Negeri 2 Banjarharjo Brebes dalam Pokok Bahasan Segiempat Melalui Model Pembelajaran Tutor Sebaya Dalam Kelompok kecil. Skripsi. Universitas Negeri Semarang. Semarang 
Russanti, P. 2012. Bertanya, Kunci Berpikir Kreatif. http://suaraguru.wordpress.com/ 2012/07/21/bertanya-kunciberpikir-kreatif/ [27 Mei 2014]

Santrock, J.W. 2008. Adolescence: Perkembangan Remaja (edisi ke12, Penerjemah: Adelar, S.B., \& Saragih, S.). Erlangga. Jakarta

Santrock, J.W. 2008. Educational Psychology (3 $3^{\text {rd }}$ Ed). McGrawHill. Boston

STR. 2011. The Essential Questions Handbook: Hundreds of Guiding Questions That Help You Plan and Teach Successful Lessons in the Content Areas. Scholastic Teaching Resources. United Kingdom

Sukasains. 2011. Bertanya, kenapa takut?.http://sukasains.com/tulisa nku/bertanya-kenapa-takut/ [26 Mei 2014]

Supriana, A. 2013. Penerapan Metode Learning Start With A Question Dalam Pembelajaran Sejarah Untuk Meningkatkan Kemampuan Mengemukakan Pendapat Siswa. Universitas Pendidikan Indonesia. Bandung

Tamasandi, D. 2014. Lima Hal yang Menyebabkan Murid Saat Ini Enggan Beranya Kepada Guru. http://sandikataku2.blogspot.com 12014/03/5-hal-yangmenyebabkan-murid-saatini.html. [27 Mei 2014]

Urip. 2012. Alasan Siswa Enggan Bertanya di Kelas. Serial online. http://urip.wordpress.com/2012/0 8/31/alasan-siswa-engganbertanya-di-kelas/ [27 Mei 2014] Walsh, J.A \& Sattes, B.D. (2005). Quality Questioning: Research-
Based Practice to Engage Every Learner. Corwin Press. California

Walsh, J.A \& Sattes, B.D. 2011. Thinking Through Quality Questioning: Deepening Student Engagement. SAGE Publication Ltd. London

Winarsih Y. 2009. Peningkatan Respon Siswa pada Pembelajaran IPS Melalui Pendekatan Keterampilan proses (PTK Pembelajaran IPS) di SMP Muhammadiyah 2 Surakarta. Skripsi. Universitas Muhammadiyah Surakarta. Surakarta 